\title{
SELECTION CRITERIA FOR CLOUD ORIENTED SYSTEM FOR DISTANCE LEARNING IN TRAINING DATABASE OF FUTURE INFORMATION TECHNOLOGY PROFESSIONALS
}

\author{
КРИТЕРІЇ ДОБОРУ ХМАРО ОРІЄНТОВАНИХ СИСТЕМ \\ ДИСТАНЦІЙНОГО НАВЧАННЯ В НАВЧАННІ БАЗ ДАНИХ \\ МАЙБУТНІХ ФАХІВЦІВ 3 ІНФОРМАЦІЙНИХ ТЕХНОЛОГІЙ
}

\author{
Olha KOROTUN, \\ Ольга КОРОТУН, \\ Candidate of Pedagogical Sciences \\ кандидат педагогічних наук \\ https://orcid.org/0000-0003-2240-7891 \\ korotun-o@ztu.edu.ua \\ Zhytomyr Polytechnic State \\ Державний університет \\ University \\ 103 Chudnivska St., \\ Zhytomyr, 10005 \\ “Житомирська політехніка" \\ $\triangle$ вул. Чуднівська, 103,
}

Original manuscript received: October 07, 2019

Revised manuscript accepted: December 11, 2019

\begin{abstract}
The article highlights the criteria and indicators for the selection of cloud-based distance learning systems in training databases of future IT professionals, namely: organizational-didactic (course program, modularity of electronic training course, presentation of educational material in different formats, testing, journal, calendar); communication (chat, forum, alerts, email, video conference); functional (integration with other cloud services, multilingualism, number of users, user roles, data warehouse). The procedure of applying the method of expert evaluation of cloud oriented system for distance learning was presented, which consisted of two stages of the questioning of experts: in the first, out of ten proposed such systems, five were selected; on the second, one out of five systems (MoodleCloud, iSpring Online, Geenio, Google Classroom, Canvas) is identified for use in the training of databases of future IT professionals. As a result, the Canvas system is found to be the most convenient. Other Instructure software products for higher education have been covered, including: Canvas Network MOOC Platform - a platform for mass open online courses; Canvas Catalog is a cloud service that allows educational institutions or individual teachers to host their e-courses; Bridge is a cloud-based, corporatebased distance learning system; Canvas Commons (integrated with Canvas) - a repository for storing educational resources, contains lesson plans, quizzes and surveys, e-courses and training programs developed by teachers of schools and higher education institutions. The study of such cloud oriented system for distance learning allowed to distinguish their characteristics for use in higher education institutions: functionality, reliability, cost of the system, modularity, perspective of system development, availability, high-quality technical support.
\end{abstract}

Keywords: cloud services, distance learning system, cloud oriented system for distance learning, training of future IT specialists, selection criteria.

Вступ. Застосування хмаро орієнтованих систем дистанційного навчання (ХОСДН) в освітньому процесі закладів вищої освіти (ЗВО) можливе 
завдяки доступу викладачів і студентів до глобальної мережі Інтернет з різних засобів: комп'ютера, ноутбука, нетбука, планшета, смартфона.

Вітчизняний учений В. Биков (Биков, 2010) виокремлює характерні властивості таких мобільних Інтернет-пристроїв: малі масогабаритні параметри i електроспоживання, довготривале автономне енергозабезпечення; планшетна (кишенькова) високоергономічна конструкція; швидкий, зручний і безпечний мультисервісний сенсорний екран з високою роздільною здатністю тощо.

Тому використання доступних суб'єктам навчання 3 різних стаціонарних і портативних пристроїв ХОСДН в освітньому процесі ЗВО зекономить кошти закладів на придбання програмного забезпечення (ПЗ), сприятиме відкритості навчального середовища, дозволить створювати персональне навчальне середовище майбутнього фрахівця $з$ інформаційних технологій й зорієнтує його на свідому самостійну навчальну діяльність.

Мета статті полягає у визначенні критеріїв добору хмаро орієнтованих систем дистанційного навчання у навчанні баз майбутніх фахівців з інформаційних технологій.

Методи та методики дослідження. Для досягнення мети дослідження використано комплекс методів: теоретичних - аналіз педагогічної літератури для вивчення стану розробленості досліджуваної проблеми; вивчення сучасного стану використання ХОСДН у ЗВО; аналіз ХОСДН; емпіричних - опитування викладачів вітчизняних ЗВО щодо використання ХОСДН, метод експертного оцінювання.

Результати та дискусії. Під ХОСДН розуміємо хмарний сервіс для організації освітнього процесу, використання якого дозволяє створювати, управляти та поширювати навчальні матеріали в електронному вигляді, контролювати й оцінювати результати навчання, формувати звітну навчальну документацію.

Л. Сардак і Л. Старкова (Сардак, Старкова, 2014) стверджують, система дистанційного навчання (СДН) - інформаційна система. ХОСДН як різновид СДН є інформаційною системою. Головні завдання такої систем - організація, обробка, зберігання, подання і передавання даних. Одним із структурних елементів ХОСДН $є$ база даних (БД).

Вивчаючи, наприклад, навчальну дисципліну "Бази даних" 3 використанням ХОСДН, майбутні фахівці з інформаційних технологій, поперше, вчаться застосовувати хмарні сервіси в освітньому процесі для досягнення дидактичних цілей; по-друге, студенти працюють з вебдодатоком для роботи з БД, виконуючи різні операції над даними БД (створення змістових модулів, зберігання навчального матеріалу, видалення і редагування завдань, пошук даних, сортування оцінок студентів, перегляд відомостей про певного студента тощо), вивчають об'єкти БД (таблиці (Користувачів, Модулів, Оцінок, Контрольний робіт тощо), форми (реєстрація нового користувача, створення завдання, додавання оголошення, створення контрольної роботи тощо), запити (на пошук користувачів за ролями, сортування таблиці оцінок тощо), звіти (активності студентів, успішності студентів, про виконання завдань 
студентами тощо)). Також майбутні фахівці з інформаційних технологій намагаються розробити орієнтовану концептуальну модель предметної області "ХОСДН". Це допоможе досягнути мети викладання дисципліни "Бази даних" - подати теоретичні відомості та сформувати практичні уміння й навички у студентів щодо проектування (визначення мети створення БД, таблиць БД, полів БД, ключів, зв'язків між таблицями, створення запитів, звітів, фрорм тощо) та адміністрування БД.

Вивченню ХОСДН присвячені праці вітчизняних науковців: А. М. Аврамчук розглядає ХОСДН MoodleCloud, робить опис ї̈ деяких характеристик; В. Артеменко висвітлює MoodleCloud i висвітлює створення хмаро орієнтованого навчального середовища (XOHC) на базі цієї системи у ЗВО; Т. Вакалюк представляє досвід використання ХОСДН NEO у навчальній діяльності; Ю. Триус описує ХОНС кафедри комп'ютерних наук та інформаційних технологій управління Черкаського державного технологічного університету на базі MoodleCloud.

Однак з'ясувалося, що ця проблема є відносно новою та потребує подальшого вивчення, зокрема в аспекті добору ХОСДН для використання у хмаро орієнтованому середовищі (XOC) навчання БД майбутніх фрахівців з інформаційних технологій.

Для визначення найбільш доцільних ХОСДН та їхньої ефективності під час навчання БД майбутніх фахівців з інформаційних технологій був застосований метод експертного оцінювання. Відповідно до цього методу ХОСДН, які розглядаються, нумеруються в порядку зростання або спадання за певною ознакою, котра $\epsilon$ основою для подальшого ранжування. Опитування експертів здійснювалося у два етапи, розглянемо їх.

Перший етап опитування експертів. Фахівцям було запропоновано оцінити 10 визначених ХОСДН, що можуть використовуватися у навчанні БД майбутніх фахівців 3 інформаційних технологій. 3 метою експертного оцінювання було залучено фахівців цього профілю - викладачів, завідувачів кафедр і деканів ЗВО України, які мають досвід та безпосередньо пов'язані 3 навчанням БД або професійною підготовкою майбутніх фахівців 3 інформаційних технологій (14 осіб).

У межах нашого дослідження скористалися бальною системою оцінки запропонованою Т. Вакалюк та О. Спіріним (Вакалюк, Спірін, 2017). Після проведення необхідних обчислень (Вакалюк, Спірін, 2017) 3 використанням експериментальних даних одержуємо певне значення W. У випадку суттєвої різниці від нуля результатів обчислення визначаємо існування об'єктивного погодження між експертами $(\mathrm{W}=0$ - зв'язок між ранжуванням експертів відсутній, $W=1$ - ранжування повністю збігаються), сумарні ранги є досить об'єктивними.

Експертам було запропоновано опитування для ранжування ХОСДН. У результаті виконання необхідних розрахунків отримали таке значення коефріцієнта конкордації $W=0,77$. Одержане значення відрізняється від нуля, тому між експертами існує об'єктивне погодження. У результаті було обрано п'ять ХОСДН у навчанні БД майбутніх фахівців з інформаційних технологій: MoodleCloud, iSpring, Geenio, Google Classroom, Canvas. 
Cucmeмa Canvas (https://canvas.instructure.com). Міграція СДН Canvas у хмару відбулася у 2015 році. Компанія Instructure використовує хостинг AWS. Доступна як на стаціонарних, так і на мобільних пристроях на 26 мовах. Викладачі можуть застосовувати ХОСДН Canvas в освітньому процесі безкоштовно, термін ії̈ використання необмежений.

Основний інструментарій системи ХОСДН Canvas включає низку функціональних можливостей: створення та управління електронними курсами, які складаються 3 модулів, що вміщують контент різного формату та послідовно публікуються; створення завдань, обговорень, контрольних робіт, зовнішніх інструментів, вікі-сторінок, тестів; імпорт готових курсів з Canvas, Moodle, Blackboard, iSpring, D2L та інших навчальних платформ; електронний журнал та залікову книжку; аналітику процесу навчання; проведення конференцій і дискусій; спільна робота з документами; інтеграцію з електронними соціальними сервісами; приймання домашніх завдань в електронному вигляді; створення різноманітних звітів; опцію об'єднання студентів у групи тощо.

Компанія Instructure, яка впроваджує IT у вищу та середню освіту, пропонує такі програмні продукти: Canvas Network MOOC Platform платформа масових відкритих онлайн-курсів; Canvas Catalog - хмарний сервіс, що дозволяє закладам освіти або окремим викладачам розміщувати свої електронні курси, організовувати реєстрацію, приймати оплату через єдину платформу; Bridge - ХОСДН для корпоративного навчання; Canvas Commons - репозиторій для зберігання навчальних ресурсів, який містить плани уроків, вікторини та опитування тощо, розроблені вчителями шкіл і викладачами ЗВО.

Вивчення основного функціоналу, тарифного плану, терміну використання, додаткових інструментів вищезазначених ХОСДН показало, що ХОСДН Canvas $€$ найбільш зручною для розв'язання навчальних завдань вищої освіти.

Виокремимо характеристики ХОСДН для використання у ЗВО: фуункціональність - визначається необхідним набором функцій для забезпечення підтримки освітнього процесу в повному обсязі, система перевірки знань, форуми, повідомлення, аналіз активності студентів тощо); надійність - означає наявність для викладача зручних засобів адміністрування курсів та простоту оновлення контенту на базі наявних шаблонів; вартість системи - наявність безкоштовної версії та недорогого тарифного плану; відповідність курсів загальновизнаним стандартам (єдиний стандарт збереження навчальних інформаційних ресурсів: специфікації, розроблені консорціумом IMS Global Learning Consortium (IMS); технології створення програмних модулів, розроблені асоціацією ADL (SCORM)); модульність - представлення навчального курсу у вигляді набору модулів навчального матеріалу; перспективність розвитку поліпшення вже наявних версій системи з підтримкою нових технологій, стандартів і засобів; доступність - доступ користувачів до системи здійснюється 3 будь-якого комп'ютерно орієнтованого засобу; якісна технічна підтримка з боку служби підтримки компанії-розробника ХОСДН. 
Другий етап опитування експертів. До дослідження залучили іншу групу фрахівців для оцінювання найбільш доцільних ХОСДН у навчанні БД згідно з виокремленими критеріями, рівень прояву кожного 3 яких оцінювався окремо для зазначених п'яти ХОСДН. Визначення фрахівцями ступеня прояву певного критерію відбувалось при оцінюванні його показників з використанням бальної шкали, запропонованою знову ж таки Т. Вакалюк та О. Спіріним (Вакалюк, Спірін, 2017).

Виокремимо критерії та їхні показники для визначення ХОСДН, які будемо використовувати в навчанні БД майбутніх учителів інформатики.

Передусім наведемо тлумачення понять "критерій" та "показник". Зазначимо, спираючись на дослідження І. Богданової (Богданова, 1997), що поняття "критерій" ширше, ніж поняття "показник". Однин критерій може містити низку показників. Іншими словами, вони є складовими критерію.

На думку В. Курило (Курило, 1999), у педагогічній теорії під критеріями розуміють ті якості явища, що відображають його суттєві характеристики і саме тому підлягають оцінці.

Отже, під критеріями добору ХОСДН у навчанні БД майбутніх фахівців з інформаційних технологій розуміємо такі характеристики і властивості ХОСДН, які $€$ необхідними для організації навчання з баз даних майбутніх фахівців з інформаційних технологій.

Аналіз ХОСДН у навчанні майбутніх фахівців з інфрормаційних технологій дозволив виокремити такі критерії та відповідні їм показники для зазначених вище ХОСДН: організаційно-дидактичний, комунікаційний, функціональний.

Висвітлимо отримані результати другого етапу експертного оцінювання кожного з критеріїв та відповідних йому показників.

Організаційно-дидактичний критерій визначає можливість організувати навчання з БД майбутніх фахівців з інформаційних технологій в ХОСДН, також містить дидактичну складову освітнього процесу з БД. До його складу входять такі показники: програма курсу - наявність пояснювальної записки та короткого опису навчальної дисципліни "Бази даних" у ХОСДН, у якому вказується зміст цієї дисципліни відповідно до НМК; модульність ЕНК - наявність можливості відобразити у ХОСДН модулі та змістові модулі навчальної дисципліни "Бази даних" згідно з НМК; представлення навчального матеріалу у різних фоорматах - навчальний матеріал у ХОСДН з бази даних може бути у таких форматах: текстовому (".doc, *.docx, *.rff), мультимедійному (електронні презентації ( $\left.{ }^{*} . p p t,{ }^{*} . p p t x,{ }^{*} . p p t s\right)$, аудіо(".mp3, *.wma ), відеофрайл (".avi, $\left.\left.{ }^{*} . w m v\right)\right)$, PDF-документі (".pdf), гіперпосиланні на ресурс у мережі Internet, html-документі (*.html), архівному файлі (*.zip, *.rar) тощо; тестування - наявність можливості проведення тестувань майбутніх фахівців з інформаційних технологій з дисципліни "Бази даних" у ХОСДН, створюючи питання різного типу; журнал - журнал оцінок навчальних досягнень майбутніх фахівців з інформаційних технологій у навчанні БД у ХОСДН; календар - наявність можливості планування навчальних подій з дисципліни "Бази даних" у ХОСДН. Представимо оцінки експертів за показникам вказаного критерію для кожної ХОСДН (табл. 1). 
Таблиця 1

Організаційно-дидактичний критерій та його показники добору ХОСДН у навчанні БД майбутніх фахівців з інформаційних

технологій

\begin{tabular}{|c|c|c|c|c|c|c|c|}
\hline Показники & 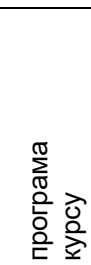 & 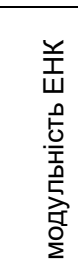 & 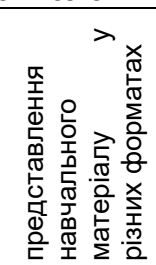 & 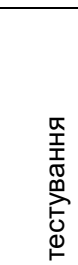 & 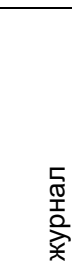 & 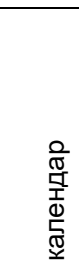 & 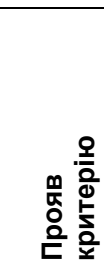 \\
\hline MoodleCloud & 1,43 & 2,5 & 2,43 & 2,57 & 2,64 & 2,71 & $83 \%$ \\
\hline iSpring & 1,36 & 2,43 & 2,29 & 2,21 & 0,00 & 1,43 & $50 \%$ \\
\hline Geenio & 0,00 & 1,43 & 2,5 & 2,14 & 0,00 & 0,00 & $33 \%$ \\
\hline Google Classroom & 0,00 & 0,00 & 2,71 & 0,00 & 0,00 & 2,86 & $33 \%$ \\
\hline Canvas & 2,71 & 2,79 & 2,79 & 2,64 & 2,79 & 2,86 & $100 \%$ \\
\hline
\end{tabular}

Комунікаційний критерій характеризує можливість викладача й майбутніх фрахівців з інформаційних технологій здійснювати комунікацію 3 дисципліни "Бази даних" у ХОСДН через: чат - наявність швидкого обміну текстовими повідомленнями в режимі реального часу між викладачем i студентами; фоорум - можливість спілкування викладача та студентів у навчанні БД у синхронному й асинхронному режимах, зокрема створення загальної теми з БД для обговорення, де кожний, кого цікавлять певні відомості може зручно й швидко переглянути їх на форумі; сповіщення наявність можливості суб'єктів навчання створювати електронні повідомлення та спілкуватися за допомогою них у ХОСДН при вивченні БД; електронна пошта - наявність обміну електронними листами, що уможливлює пересилання даних різного формату (текстові документи, аудіо, відеофайли, архіви, програми тощо); відеоконференція - наявність можливості створення конференцій за допомогою відкритого ПЗ для проведення веб-конфреренцій, наприклад, BigBlueButton. Покажемо результати за показниками цього критерію для кожної ХОСДН (табл.2).

Таблиця 2

Комунікаційний критерій та його показники добору ХОСДН у навчанні БД майбутніх фахівців з інформаційних технологій

\begin{tabular}{|c|c|c|c|c|c|c|}
\hline Показники & $\frac{\mathfrak{T}}{\sigma}$ & $\begin{array}{l}\sum_{0}^{2} \\
8 \\
8\end{array}$ & 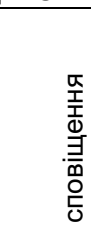 & 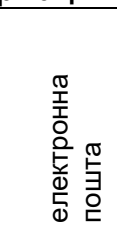 & 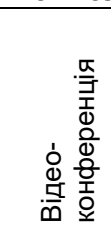 & 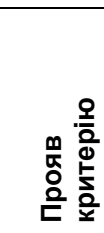 \\
\hline MoodleCloud & 2,43 & 1,93 & 2,50 & 0,00 & 2,21 & $80 \%$ \\
\hline iSpring & 0,00 & 2,50 & 0,00 & 0,00 & 0,00 & $20 \%$ \\
\hline Geenio & 0,00 & 0,00 & 0,00 & 0,00 & 0,00 & $0 \%$ \\
\hline Google Classroom & 0,00 & 0,00 & 2,36 & 0,00 & 0,00 & $20 \%$ \\
\hline Canvas & 1,64 & 2,79 & 2,64 & 2,86 & 2,71 & $100 \%$ \\
\hline
\end{tabular}

ICV 2018: 77.58 
Серія: Педагогічні науки. - Вип.3. - Бердянськ : БДПУ, 2019. - 453 с.

Функціональний критерій визначає функціональну складову ХОСДН у навчанні БД майбутніх фахівців з інформаційних технологій: інтеграція з іншими хмарними сервісами - наявність можливості додавання нових функцій шляхом інтеграції хмарних сервісів; багатомовність - наявність можливості змінити мову та підтримка різних мов інтерфейсу; кількість користувачів - наявність можливості реєстрації більше 50 майбутніх фахівців з інформаційних технологій; ролі користувачів - реєстрація користувачів (викладача і студентів) з різним набором можливостей та дозволів; сховище даних - наявність онлайнсховища даних навчального матеріалу з дисципліни "Бази даних" у системі. Представимо результати за показниками функціонального критерію для кожної ХОСДН (табл.3).

Таблиця 3

Функціональний критерій та його показники добору ХОСДН у навчанні БД майбутніх фахівців з інформаційних технологій

\begin{tabular}{|c|c|c|c|c|c|c|}
\hline Показники & 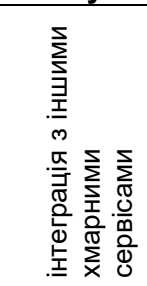 & 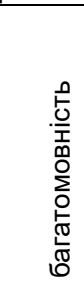 & 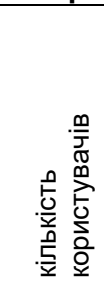 & 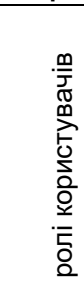 & 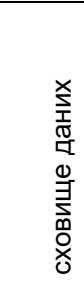 & 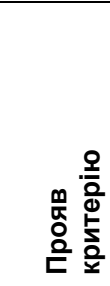 \\
\hline MoodleCloud & 1,43 & 2,36 & 0,00 & 2,50 & 2,43 & $60 \%$ \\
\hline iSpring & 0,00 & 2,36 & 1,29 & 1,43 & 1,36 & $20 \%$ \\
\hline Geenio & 0,00 & 1,93 & 0,00 & 1,79 & 2,00 & $40 \%$ \\
\hline Google Classroom & 2,93 & 2,43 & 2,43 & 1,43 & 2,50 & $80 \%$ \\
\hline Canvas & 2,93 & 2,50 & 2,57 & 2,79 & 2,64 & $100 \%$ \\
\hline
\end{tabular}

Продемонструємо підсумкову таблицю результатів прояву всіх критеріїв обраних ХОСДН майбутніх фахівців з інформаційних технологій (табл. 4).

Таблиця 4

Результати прояву всіх критеріїв в обраних ХОСДН

\begin{tabular}{|l|l|l|l|}
\hline $\begin{array}{l}\text { Критерій } \\
\text { хосдн }\end{array}$ & $\begin{array}{l}\text { Організаційно- } \\
\text { дидактичний }\end{array}$ & Комунікаційний & Функціональний \\
\hline MoodleCloud & $83 \%$ & $80 \%$ & $60 \%$ \\
\hline iSpring & $50 \%$ & $20 \%$ & $20 \%$ \\
\hline Geenio & $33 \%$ & $0 \%$ & $40 \%$ \\
\hline Google Classroom & $33 \%$ & $20 \%$ & $80 \%$ \\
\hline Canvas & $100 \%$ & $100 \%$ & $100 \%$ \\
\hline
\end{tabular}

Отже, враховуючи результати дослідження та термін надання безкоштовної версії компаніями-розробниками обраних ХОСДН, встановлено, що ХОСДН Canvas $€$ найбільш зручною у використанні в навчанні БД майбутніх фахівців з інформаційних технологій в ХОС.

Висновки. При доборі ХОСДН варто враховувати визначені організаційно-дидактичний, комунікаційний та функціональний критерії. А 
при доборі ХOЗ у навчанні БД такі критерії та показники: функціональнодидактичний (можливість створення, редагування та видалення таблиць у БД; визначення первинних та зовнішніх ключів у таблиці; створення зв'язків між таблицями БД; модифікація даних у таблицях БД; можливість аналізу результатів та помилок у запитах), організаційний (доступність; підтвердження фінансової спроможності користувача; зручність використання). Це дозволить із усього різноманіття програмних засобів виокремити лише ті, що можуть бути впровадженні в процес навчання баз даних із використанням ХОС. Щоб ХОСДН можна було використовувати в освітньому процесі ЗВО, системи повинні відповідати таким характеристикам: функціональність, надійність, вартість системи, відповідність курсів загальновизнаним стандартам, модульність, перспективність розвитку ХОСДН, доступність, якісна технічна підтримка. Вивчення складових ХОСДН дозволило визначити ії загальну функціональну та орієнтовану технічну структуру.

\section{Література}

1.Биков В. Ю. Відкрите навчальне середовище та сучасні мережні інструменти систем відкритої освіти [Електронний ресурс]. Науковий часопис Національного педагогічного університету імені М. П. Драгоманова. Серія 2: Комп'ютерно-орієнтовані системи навчання: збірник наук. пр. - 2010. - Вип. 9(16). - C. 9-16.

2.Сардак Л. В., Старкова Л. М. Построение модульной системы управления обучением в высшей школе средствами облачных сервисов. Инфрормационно-коммуникационные технологии в образовании. - 2014. - № 8. C. $120-127$.

3.Спірін О. М., Вакалюк Т. А. Критерії добору відкритих web-орієнтованих технологій навчання основ програмування майбутніх учителів інформатики. Інформаційні технології і засоби навчання. - 2017. - № 4(60). - С. 275-287.

4.Триус Ю. В. Хмаро-орієнтоване навчальне середовище кафедри ВН3 на платформі MoodleCloud. Четверта міжнародна науково-практична конфреренція "MoodleMoot Ukraine 2016. Теорія і практика використання системи управління навчанням Moodle" (м. Київ, КНУБА, 19-20 травня 2016 р.): тези доп. - Київ, 2016. C. 18-19.

5.Богданова І. М. Модульна технологія у професійній підготовці вчителя: монографрія / За ред. І. А. Зязюна. - Одеса: Учбова книга - 1997. - 289 с.

6.Курило В. С. Моделювання системи критеріїв оцінки розвитку освіти в регіоні. Педагогіка і психологія. - 1999. - № 2. - С. 35-39.

\section{References}

1.By'kov V. Yu. Open learning environment and modern open-source networking tools [Elektronny`j resurs]. Naukovy`j chasopy`s Nacional'nogo pedagogichnogo universy'tetu imeni M. P. Dragomanova. Seriya 2: Komp'yuternooriyentovani sy`stemy` navchannya: zbirny`k nauk. pr. - 2010. - Vy`p. 9(16). - S. 9-16. [inUkrainian].

2.Sardak L. V., Starkova L. M. Establishment of a modular system of management training in higher education by means of cloud services. Y'nformacy' onno-kommuny 'kacy'onnde texnology 'y' v obrazovany ' $y$ '. - 2014. - \# 8. S. 120-127. [inUkrainian].

3.Spirin O. M., Vakalyuk T. A. Selection criteria for open web-based 
technologies for teaching the basics of programming to future computer science teachers.. Informacijni texnologiyi i zasoby navchannya. - 2017. - \# 4(60). - S. 275287. [inUkrainian].

4.Try us Yu. V. Cloud oriented learning environment of the MoodleCloud platform.. Chetverta mizhnarodna naukovo-prakty`chna konferenciya "MoodleMoot Ukraine 2016. Teoriya i prakty `ka vy`kory`stannya sy`stemy` upravlinnya navchannyam Moodle" (m. Ky`yiv, KNUBA, 19-20 travnya 2016 r.): tezy` dop. - Ky`yiv, 2016. - S. 1819. [inUkrainian].

5.Bogdanova I. M. Modular technology in teacher training: monografiya / Za red. I. A. Zyazyuna. - Odesa: Uchbova kny`ga - 1997. - 289 s.

6. Kury lo V. S Modeling the system of criteria for assessing the development of education in the region. Pedagogika i psy xologiya. - 1999. - \# 2. - S. 35-39. [inUkrainian].

\section{АНОТАЦІЯ}

У статті виокремлено критерії та показники добору хмаро орієнтованих систем дистанційного навчання у навчанні баз даних майбутніх фахівців з інформаційних технологій, а саме: організаційно-дидактичний (програма курсу, модульність електронного навчального курсу, представлення навчального матеріалу у різних фрорматах, тестування, журнал, календар); комунікаційний (чат, форум, сповіщення, електронна пошта, відеоконференція); функціональний (інтеграція з іншими хмарними сервісами, багатомовність, кількість користувачів, ролі користувачів, сховище даних). Представлена процедура застосування методу експертного оцінювання хмаро орієнтованих систем дистанційного навчання, що складалася з двох етапів опитування експертів: на першому - з десяти запропонованих таких систем було обрано п'ять; на другому - з виокремлених п'ти систем (MoodleCloud, iSpring Online, Geenio, Google Classroom, Canvas) визначена одна для використання у навчанні баз даних майбутніх фрахівців з інформаційних технологій. У результаті виявлено, що система Canvas $\epsilon$ найбільш зручною. Висвітлено інші програмні продукти компанії Instructure для застосування у вищій освіті, зокрема: Canvas Network MOOC Platform - платформа масових відкритих онлайн-курсів; Canvas Catalog - хмарний сервіс, що дозволяє закладам освіти або окремим викладачам розміщувати свої електронні курси; Bridge - хмаро орієнтована система дистанційного навчання для корпоративного навчання; Canvas Commons (інтегрована з Canvas) - репозиторій для зберігання навчальних ресурсів, містить плани уроків, вікторини та опитування, електронні курси і навчальні програми, розроблені вчителями шкіл та закладів вищої освіти. Вивчення таких хмаро орієнтованих систем дистанційного навчання дозволило виокремити їх характеристики для використання у закладі вищої освіти: функціональність, надійність, вартість системи, модульність, перспективність розвитку системи, доступність, якісна технічна підтримка.

Ключові слова: хмарні сервіси, система дистанційного навчання, хмаро орієнтована система дистанційного навчання, підготовка майбутніх фахівців $з$ інформаційних технологій, критерії добору. 